\title{
Genes involved in carnitine synthesis and carnitine uptake are up-regulated in the liver of sows during lactation
}

\author{
Susann Rosenbaum ${ }^{1 \dagger}$, Robert Ringseis ${ }^{1{ }^{* \dagger}}$, Erika Most ${ }^{1}$, Sonja Hillen ${ }^{2}$, Sabrina Becker ${ }^{2}$, Georg Erhardt ${ }^{3}$,
} Gerald Reiner ${ }^{2}$ and Klaus Eder ${ }^{1}$

\begin{abstract}
Background: Convincing evidence exist that carnitine synthesis and uptake of carnitine into cells is regulated by peroxisome proliferator-activated receptor a (PPARA), a transcription factor which is physiologically activated during fasting or energy deprivation. Sows are typically in a negative energy balance during peak lactation. We investigated the hypothesis that genes involved in carnitine synthesis and uptake in the liver of sows are upregulated during peak lactation.

Findings: Transcript levels of several PPARa target genes involved in fatty acid uptake (FABP4, SLC25A20), fatty acid oxidation (ACOX1, CYP4A24) and ketogenesis (HMGCS2, FGF21) were elevated in the liver of lactating compared to non-lactating sows $(P<0.05)$. In addition, transcript levels of genes involved in carnitine synthesis (ALDH9A1, TMLHE, BBOX1) and carnitine uptake (SLC22A5) in the liver were greater in lactating than in non-lactating sows $(P<0.05)$. Carnitine concentrations in liver and plasma were about $20 \%$ and $50 \%$, respectively, lower in lactating than in non-lactating sows $(P<0.05)$, which is likely due to an increased loss of carnitine via the milk.

Conclusions: The results of the present study show that PPARa is activated in the liver of sows during lactation which leads to an up-regulation of genes involved in carnitine synthesis and carnitine uptake. The PPARa mediated up-regulation of genes involved in carnitine synthesis and uptake in the liver of lactating sows may be regarded as an adaptive mechanism to maintain hepatic carnitine levels at a level sufficient to transport excessive amounts of fatty acids into the mitochondrion.
\end{abstract}

Keywords: Lactation, Sow, Liver, PPARa pathway, Carnitine

\section{Findings}

Lactation is associated with a dramatic increase in the energy and nutrient requirement of the organism for milk production which is usually met by an elevation of food intake, a mobilisation of body's energy stores, and several metabolic adaptations $[1,2]$. In order to improve the knowledge about metabolic adaptations during lactation in sows we have recently analyzed the changes in the hepatic transcriptome of sows during lactation using a porcine whole-genome microarray [3]. Interestingly, enrichment analysis using the Kyoto Encyclopedia of

\footnotetext{
* Correspondence: robert.ringseis@ernaehrung.uni-giessen.de

${ }^{\dagger}$ Equal contributors

'Institute of Animal Nutrition and Nutritional Physiology,

Justus-Liebig-University, Heinrich-Buff-Ring 26-32, Giessen 35392, Germany

Full list of author information is available at the end of the article
}

Genes and Genomes (KEGG) database revealed that peroxisome proliferator-activated receptor $\alpha(\mathrm{PPAR} \alpha)$ signalling is one of the regulatory pathways which is activated in the liver of sows during lactation [3]. PPAR $\alpha$ is a ligand-activated transcription factor which induces of a large set of genes encoding proteins involved in fatty acid catabolism, such as fatty acid activation, fatty acid $\beta$-oxidation, fatty acid hydroxylation, ketogenesis and gluconeogenesis $[4,5]$. This transcription factor is known to be activated by non-esterified fatty acids (NEFA) [4,5], which are released from adipose tissue during early lactation due to the strong increase in the sow's energy requirement for milk production which cannot be completely covered by an increase of feed intake [3]. Genes involved in fatty acid catabolism are up-regulated

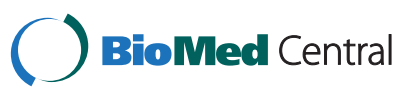


by PPAR $\alpha$ because the regulatory regions of these genes contain specific DNA sequences, called peroxisome proliferator response elements (PPRE), which are bound by the activated PPAR $\alpha$ complex and mediate transcription of these genes $[4,5]$. Studies in mice, rats and pigs indicated that PPAR $\alpha$ is not only a critical regulator of fatty acid catabolic genes but also a key regulator of genes involved in carnitine synthesis and uptake [6]. In pigs, carnitine biosynthesis occurs exclusively in liver and kidney, with liver being quantitatively most important [7]. Convincing evidence for the regulation of genes involved in carnitine synthesis and uptake by PPAR $\alpha$ has been provided from genetic studies in which functional PPRE have been identified in the regulatory regions of the mouse genes encoding the carnitine transporter novel organic cation transporter 2 (OCTN2/ SLC22A5) and two enzymes of the carnitine biosynthetic pathway, $\gamma$-butyrobetaine dioxygenase (BBOX1) and 4trimethylaminobutyraldehyde dehydrogenase (ALDH9A1) [8-10]. Like in lactating sows, activation of hepatic PPAR $\alpha$ and up-regulation of fatty acid catabolic genes in the liver has been reported in early lactating cows [11-13]. In addition, induction of genes involved in carnitine synthesis and uptake (SLC22A5, BBOX1, ALDH9A1) in the liver and a marked increase in the hepatic carnitine concentration has been observed in cows during lactation [14]. The increase in the hepatic concentration of carnitine in the early lactating cow has been interpreted as a means to supply the liver with sufficient carnitine required for transport of excessive amounts of fatty acids into the mitochondrion. Regarding that PPAR $\alpha$ is activated and genes involved in fatty acid catabolism are up-regulated also in the liver of sows during lactation, we tested the hypothesis that genes involved in carnitine synthesis and uptake are up-regulated in the liver of sows during peak lactation.

The animal study was conducted in accordance with established guidelines for the care and handling of laboratory animals and was approved by the local Animal Welfare Authorities (Regierungspräsidium Giessen; permission no: GI 19/3-No. 29/2010). The experiment included twenty second parity sows (Large White \& German Landrace), which were artificially inseminated with semen from boars of the own breed, and kept in single crates until day 21 of pregnancy. From day 21 to 110 of pregnancy the sows were kept in groups in pens that had fully slatted floors, nipple drinkers and feeding stations, and from day 110 of pregnancy until farrowing the sows were housed in single farrowing pens. During pregnancy, all sows received a commercial diet for gestating sows ad libitum. $24 \mathrm{~h}$ after farrowing, the sows were randomly assigned into two groups of 10 animals each. In the first group of sows designated as "nonlactating group" (average body weight: $259 \pm 17 \mathrm{~kg}$ ), all piglets were removed from the sow $24 \mathrm{~h}$ after farrowing.
In the second group of sows designated as "lactating group" (average body weight: $256 \pm 17 \mathrm{~kg}$ ), litters were standardised to 12 piglets per sow. To ensure an adequate temperature of $35^{\circ} \mathrm{C}$ for the piglets an infrared heater was placed directly above the site of the newborn piglets. The temperature and the relative humidity in the dry sow accommodation and the farrowing unit were kept at $19 \pm 1^{\circ} \mathrm{C}$ and $60-80 \%$, respectively, by means of an air conditioning system. In addition, a light:dark cycle of 12-h light and 12-h dark was applied. During lactation until the end of the experiment the sows were given a diet for lactating sows. Until day 6 of lactation, the amount of feed given to the lactating sows was successively increased $(1.6 \mathrm{~kg} / \mathrm{d}$ on day $1 ; 2.6 \mathrm{~kg} / \mathrm{d}$ on day $2 ; 4.1 \mathrm{~kg} / \mathrm{d}$ on day 3 ; $5 \mathrm{~kg} / \mathrm{d}$ on day $4 ; 5.5 \mathrm{~kg} / \mathrm{d}$ on day 5 and $6.0 \mathrm{~kg} / \mathrm{d}$ on day 6 ), and from day 7 of lactation and thereafter the sows received individual amounts of feed depending on their body weights. In the non-lactating group, each sow was given an amount of food sufficient to cover the individual energy and nutrient requirement for maintenance.

The diet for gestating sows consisted of (in $\mathrm{g} / \mathrm{kg} \mathrm{diet):}$ wheat (160), barley (705), soy bean meal with $43 \%$ crude protein (80), soy oil (5) and a mineral supplement (50) (Sano Fasersan Trag $^{\circledR}$, Sano-Moderne Tierernährung $\mathrm{GmbH}$, Loiching, Germany) and had a metabolizable energy of $12.2 \mathrm{MJ}$ per $\mathrm{kg}$ diet. The diet for lactating sows consisted of (in $\mathrm{g} / \mathrm{kg} \mathrm{diet):} \mathrm{wheat} \mathrm{(440),} \mathrm{barley} \mathrm{(350),} \mathrm{soy}$ bean meal with $43 \%$ crude protein (160), soy oil (15) and a mineral supplement (35) (Sauengold Lac ${ }^{\circledR}$, Sano-Moderne Tierernährung $\mathrm{GmbH}$, Loiching, Germany) and had a metabolizable energy of $13.1 \mathrm{MJ}$ per $\mathrm{kg}$ diet. Both types of diets (gestation and lactation) were not supplemented with carnitine. The native carnitine concentration of the diets was very low ( $<5 \mathrm{mg} / \mathrm{kg}$ diet) as determined by tandem mass spectrometry (see below).

On day 20 after farrowing, blood was collected from $V$. jugularis $3 \mathrm{~h}$ after feed intake in heparinised polyethylene tubes (Sarstedt, Nürnberg, Germany) and plasma was obtained by centrifugation and stored at $-20^{\circ} \mathrm{C}$. Liver samples were taken by biopsy which took place in a cleaned and disinfected room in the animal keeping facility. Anesthetization of the sows was carried out as described recently in detail [3]. The liver biopsy samples were taken percutaneously in the left lateral cumbency with a $16 \mathrm{G} / 1.65 \mathrm{~mm}$ biopsy needle (length: $160 \mathrm{~mm}$ ) on a HistoCore ${ }^{\circledR}$ system (BIP Biomed. Instrumente \& Produkte $\mathrm{GmbH}$, Germany) as described elsewhere [15]. Liver samples were immediately snapfrozen and stored at $-80^{\circ} \mathrm{C}$ until analysis. Total RNA from frozen liver samples was isolated using TrizolTM reagent (Invitrogen, Karlsruhe, Germany) according to the manufacturer's protocol and purified using the RNeasy Minikit (Qiagen, Hilden, Germany). cDNA synthesis and quantitative real-time PCR (qPCR) analysis 
were performed as described recently in detail [16]. Characteristics of primers and primer performance data used for qPCR analysis are shown in Table 1. Concentrations of free carnitine and acetylcarnitine in plasma, liver and diets were determined by tandem mass spectrometry according to Hirche et al. [17]. Statistical analysis was performed by one way analysis of variance. Fisher's multiple range test was used to generate significant $\mathrm{F}$-values of differences with $\mathrm{P}<0.05$.

Like in dairy cows, the transition from pregnancy to lactation in sows is associated with severe metabolic adaptations. The production of milk causes a strong increase of the sow's energy requirement which however cannot be completely covered by an increase of feed intake. Indeed, the sows of the lactating group exhibited a greater loss of body weight from day 1 to day 20 of lactation than sows of the non-lactating group, despite showing a markedly greater feed intake [3]. In line with this, we found that the sows of the lactating group are in a strong negative energy balance during this period [3]. To compensate the negative energy balance NEFA are typically mobilized from adipose tissue which was

Table 1 Characteristics of primers and primer performance data used for qPCR

\begin{tabular}{|c|c|c|c|c|c|c|c|}
\hline $\begin{array}{l}\text { Gene } \\
\text { symbol }\end{array}$ & $\begin{array}{l}\text { Forward primer (from } 5^{\prime} \text { to } 3^{\prime} \text { ) } \\
\text { Reverse primer (from } 5^{\prime} \text { to } 3^{\prime} \text { ) }\end{array}$ & $\begin{array}{l}\text { Product } \\
\text { size (bp) }\end{array}$ & $\begin{array}{c}\text { NCBI } \\
\text { GenBank }\end{array}$ & Slope & $\mathbf{R 2}^{\#}$ & Efficiency* & $M$ \\
\hline \multicolumn{8}{|l|}{ Reference genes } \\
\hline \multirow[t]{2}{*}{ RSP9 } & GTCGCAAGACTTATGTGACC & 325 & XM_003356050 & -0.28 & 0.999 & 1.91 & 0.053 \\
\hline & AGCTTAAAGACCTGGGTCT & & & & & & \\
\hline \multirow[t]{2}{*}{ ATP5G1 } & CAGTCACCTTGAGCCGGGCGA & 94 & NM_001025218 & -0.30 & 0.998 & 1.99 & 0.054 \\
\hline & TAGCGCCCCGGTGGTTTGC & & & & & & \\
\hline \multirow[t]{2}{*}{ GSR } & AGCGCGATGCCTACGTGAGC & 175 & AY368271 & -0.29 & 0.997 & 1.94 & 0.055 \\
\hline & GGTACGCCGCCTGTGGCAAT & & & & & & \\
\hline \multirow[t]{2}{*}{ ACTB } & GACATCCGCAAGGACCTCTA & 205 & XM_003124280 & -0.32 & 0.992 & 2.10 & 0.064 \\
\hline & ACATCTGCTGGAAGGTGGAC & & & & & & \\
\hline \multirow[t]{2}{*}{ SHAS2 } & GAAAAGGCTAACCTACCCTG & 218 & NM_214053 & -0.21 & 0.996 & 1.65 & 0.076 \\
\hline & TGTTGGACAAGACCAGTTGG & & & & & & \\
\hline \multicolumn{8}{|l|}{ Target genes } \\
\hline \multirow[t]{2}{*}{ ACOX1 } & CTCGCAGACCCAGATGAAAT & 218 & AF185048 & -0.28 & 0.995 & 1.90 & \\
\hline & TCCAAGCCTCGAAGATGAGT & & & & & & \\
\hline \multirow[t]{2}{*}{ ALDH9A1 } & GCTGCTGGCCGAAATCTATA & 215 & XM_001924860 & -0.29 & 0.999 & 1.94 & \\
\hline & CACACTTCCAGTGAAGGAGA & & & & & & \\
\hline \multirow[t]{2}{*}{$\mathrm{BBOX} 1$} & GTGCCGAAAGCTCAAGGAAAAA & 342 & XM_003122909 & -0.31 & 0.985 & 2.06 & \\
\hline & CTCTGCCGGCCGTGAAGTAAC & & & & & & \\
\hline \multirow[t]{2}{*}{ CYP4A24 } & GGTTTGCTCCTGTTGAATGG & 121 & NM_214424 & -0.29 & 0.999 & 1.96 & \\
\hline & GCATCACTTGGACAGACTTG & & & & & & \\
\hline \multirow[t]{2}{*}{ FABP4 } & CACCAGGAAGGTGGCTGGCA & 197 & NM_001002817 & -0.30 & 0.999 & 1.98 & \\
\hline & CCTGTACCAGGGCGCCTCCA & & & & & & \\
\hline \multirow[t]{2}{*}{ FGF21 } & GAAGCCAGGGGTCATTCAAA & 149 & NM_001163410 & -0.31 & 0.999 & 2.03 & \\
\hline & GGTAAACGTTGTAGCCATCC & & & & & & \\
\hline \multirow[t]{2}{*}{ HMGCS2 } & GGACCAAACAGACCTGGAGA & 198 & NM_214380 & -0.32 & 0.994 & 2.07 & \\
\hline & ATGGTCTCAGTGCCCACTTC & & & & & & \\
\hline \multirow[t]{2}{*}{ SLC22A5 } & TGACCATATCAGTGGGCTA & 384 & XM_003123912 & -0.30 & 0.995 & 2.00 & \\
\hline & AGTAGGGAGACAGGATGCT & & & & & & \\
\hline \multirow[t]{2}{*}{ SLC25A20 } & GCAAAGCCCATTAGCCCTCT & 312 & XM_003483178 & -0.28 & 0.998 & 1.89 & \\
\hline & GAGCACATCCTCTGGGTGTT & & & & & & \\
\hline \multirow[t]{2}{*}{ TMLHE } & GCACCATACAGCCTCCAAGT & 221 & XM_003135511 & -0.35 & 0.995 & 1.79 & \\
\hline & TGGTCTCATCCAGACGAACA & & & & & & \\
\hline
\end{tabular}

${ }^{\#}$ Coefficient of determination of the standard curve. ${ }^{*}$ The efficiency is determined by [10 $\left.{ }^{\text {-slope }}\right]$. 
demonstrated in the present study by elevated plasma levels of NEFA in the lactating compared to the nonlactating sows [3]. NEFA are then transported via the circulation to the tissues, mainly the liver, from which they are taken up and where they bind to and activate PPAR $\alpha$ [18]. In agreement with this, we observed in the present study that the negative energy balance in sows of the lactating group was associated with strongly elevated (2 to 10-fold) transcript levels of several PPAR $\alpha$ target genes involved in fatty acid uptake (FABP4, SLC25A20), fatty acid oxidation (ACOX1, CYP4A24) and ketogenesis (HMGCS2, FGF21) $(\mathrm{P}<0.05$, Table 2). Given that the above mentioned genes contain functional PPRE motifs in their regulatory regions [5], the up-regulation of these genes during lactation indicates, at least indirectly, that the PPAR $\alpha$ pathway is indeed activated in the liver of lactating sows. Due to the limited amount of liver tissue obtained from the biopsy sampling procedure additional assays, such as EMSA, providing direct evidence for activation of PPAR $\alpha$ could not be conducted. Due to the same reason protein levels of the PPAR $\alpha$ target genes were not determined. However, several studies clearly showed that increased mRNA levels of PPAR $\alpha$ target genes positively correlate with elevated levels of the encoded proteins [19], and are therefore suitable indicators of PPAR $\alpha$ activation.

In accordance with the hypothesis of this study, we found for the first time that lactation causes an up-regulation of genes involved in carnitine synthesis (ALDH9A1, TMLHE, BBOX1) and carnitine uptake (SLC22A5) in the liver of sows $(\mathrm{P}<0.05$, Table 3$)$. Considering that at least the mouse genes encoding ALDH9A1, BBOX1 and SLC22A5 were shown to be direct PPAR $\alpha$ target genes [8-10], it is very likely that the up-regulation of these genes in the liver of lactating sows was caused by the activation of PPAR $\alpha$. This assumption

Table 2 Relative transcript levels of classical PPARa target genes involved in fatty acid uptake, fatty acid oxidation and ketogenesis in the liver of lactating and non-lactating sows on day 20 of lactation

\begin{tabular}{ccc}
\hline & Non-lactating $(\mathbf{n}=\mathbf{1 0})$ & Lactating $(\mathbf{n}=\mathbf{1 0})$ \\
\hline Fatty acid uptake & $1 \pm 0.36$ & $1.88 \pm 0.87^{*}$ \\
FABP4 & $1 \pm 0.60$ & $4.63 \pm 1.02^{*}$ \\
SLC25A20 & & \\
Fatty acid oxidation & $1 \pm 0.59$ & $2.43 \pm 1.47^{*}$ \\
ACOX1 & $1 \pm 0.41$ & $2.14 \pm 1.47^{*}$ \\
CYP4A24 & & \\
Ketogenesis & $1 \pm 0.70$ & $4.86 \pm 2.25^{*}$ \\
FGF21 & $1 \pm 1.14$ & $9.63 \pm 6.67^{*}$ \\
HMGCS2
\end{tabular}

Values represent mean \pm SD for $n=10$ sows per group. *Significantly different from non-lactating group $(P<0.05)$.
Table 3 Relative transcript levels of genes involved in carnitine synthesis and carnitine uptake in the liver of lactating and non-lactating sows on day 20 of lactation

\begin{tabular}{ccc}
\hline & Non-lactating $(\mathbf{n}=\mathbf{1 0})$ & Lactating $(\mathbf{n}=\mathbf{1 0})$ \\
\hline Carnitine uptake & $1 \pm 0.24$ & $1.54 \pm 0.51^{*}$ \\
SLC22A5 & & \\
Carnitine synthesis & $1 \pm 0.55$ & $2.72 \pm 1.04^{*}$ \\
ALDH9A1 & $1 \pm 0.41$ & $1.54 \pm 0.34^{*}$ \\
TMLHE & $1 \pm 0.43$ & $2.97 \pm 0.96^{*}$ \\
BBOX1
\end{tabular}

Values represent mean $\pm S D$ for $n=10$ sows per group. *Significantly different from non-lactating group $(P<0.05)$.

is strongly supported by the fact that the functional PPRE identified in the mouse SLC22A5 gene is completely identical (100\%) and the functional PPREs of mouse ALDH9A1 and BBOX1 show a high similarity between mouse and pig [6]. In addition, treatment with the synthetic PPAR $\alpha$ activator clofibrate [20] and food deprivation [21] was reported to cause a marked upregulation of SLC22A5 and BBOX1 and an increase in the activity of butyrobetaine dioxygenase (encoded by BBOX1), the rate-limiting enzyme of carnitine synthesis, in the liver of pigs. Moreover, treatment with clofibrate [20] and food deprivation [21] causes a significant increase in the hepatic concentration of carnitine in pigs. In the present study we found that the carnitine concentration in the liver was approximately $20 \%$ lower in lactating than in non-lactating sows (Free carnitine: $43.88 \pm$ 9.13 vs. $56.1 \pm 11.5 \mathrm{nmol} / \mathrm{g}$ wet weight, $\mathrm{n}=10 /$ group, $\mathrm{P}<0.05)$, despite the strong increase in the expression of genes involved in carnitine synthesis and uptake. In addition, the concentration of carnitine in plasma was even about 50\% lower in lactating than in non-lactating sows (Free carnitine: $6.71 \pm 0.63$ vs. $12.90 \pm 0.98 \mu \mathrm{mol} / \mathrm{L}$, Acetylcarnitine: $0.73 \pm 0.16 \mathrm{vs}$. $1.53 \pm 0.20 \mu \mathrm{mol} / \mathrm{L}, \mathrm{n}=10 /$ group, both $\mathrm{P}<0.001$ ), which is likely due to loss of carnitine from the body pool via the milk. Notably, milk of sows is rich in carnitine. Carnitine concentrations in sows' milk were reported to be in the range between 120 and $185 \mu \mathrm{mol} /$ $\mathrm{L}$, depending on the stage of lactation [22,23]. Thus, production of $8-10$ liter of milk per day is associated with a loss of 1 to 2 mmoles of carnitine, an amount which is in great excess of the whole plasma carnitine pool. Thus, mobilisation of carnitine from tissue stores and an increase in carnitine synthesis rate might be important for supplying carnitine for milk. These observations, therefore, suggest that the PPAR $\alpha$ mediated up-regulation of genes involved in carnitine synthesis and uptake in the liver of lactating sows is an adaptive mechanism to maintain hepatic carnitine levels at a level sufficient to transport excessive amounts of fatty acids 
into the mitochondrion. However, the lower hepatic carnitine level in the liver of lactating than in non-lactating sows indicates that the increase in carnitine synthesis and uptake in the liver of lactating sows cannot completely compensate the loss of carnitine via the milk.

Previous studies have shown that supplementation of carnitine to sows during pregnancy offers beneficial effects on fetal growth and muscle development, number of piglets born and piglet and litter weights at birth [24-27]. It has been assumed that these effects of carnitine were mediated by influencing the secretion of IGF-1 and insulin and by an increased intrauterine nutrition of fetuses $[24,25,28]$. In contrast, supplementation of carnitine during lactation had less effects on sow and litter performance [22,24]. Thus, our observation of an increased expression of enzymes of carnitine synthesis in the liver during lactation, indicative of an increased carnitine biosynthesis, could provide an explanation for the opposite effects of carnitine supplementation in pregnancy and lactation.

In conclusion, the results of the present study show that the PPAR $\alpha$ pathway is activated in the liver of sows during lactation which leads to an up-regulation of genes involved in carnitine synthesis and carnitine uptake. The PPAR $\alpha$ mediated up-regulation of genes involved in carnitine synthesis and uptake in the liver of lactating sows may be regarded as an adaptive means to maintain hepatic carnitine levels at a level sufficient to transport excessive amounts of fatty acids into the mitochondrion.

\section{Competing interests}

The authors declare that they have no competing interests.

\section{Authors' contributions}

SR conducted the animal experiment, performed the PCR analyses and the statistical analyses and wrote the manuscript. RR supervised PCR analyses and helped to draft the manuscript. SH and GR established the liver biopsy sampling procedure. SL conducted liver biopsy sampling. GE was responsible for animal keeping. KE conceived of the study, participated in its design and coordination and helped to draft the manuscript. All authors read and approved the final manuscript.

\section{Acknowledgements}

This study was supported by the German Research Foundation (Deutsche Forschungsgemeinschaft; Grant no. ED 70/9-1).

\section{Author details}

${ }^{1}$ Institute of Animal Nutrition and Nutritional Physiology,

Justus-Liebig-University, Heinrich-Buff-Ring 26-32, Giessen 35392, Germany.

${ }^{2}$ Department of Veterinary Clinical Sciences, Swine Diseases,

Justus-Liebig-University, Frankfurter Straße 112, Giessen 35392, Germany.

${ }^{3}$ Institute for Animal Breeding and Genetics, Justus-Liebig-University,

Ludwigstraße 21b, Giessen 35390, Germany.

Received: 17 January 2013 Accepted: 7 March 2013

Published: 14 March 2013

\section{References}

1. Trayhurn P, Douglas JB, McGuckin MM: Brown adipose tissue thermogenesis is 'suppressed' during lactation in mice. Nature 1982 298:59-60.
2. Williamson $\mathrm{DH}$ : Regulation of metabolism during lactation in the rat. Reprod Nutr Dev 1986, 26:597-603.

3. Rosenbaum S, Ringseis R, Hillen S, Becker S, Erhardt G, Reiner G, Eder K: Genome-wide transcript profiling indicates induction of energygenerating pathways and an adaptive immune response in the liver of sows during lactation. Comp Biochem Physiol Part D Genomics Proteomics 2012, 7:370-381.

4. Kersten S, Seydoux J, Peters JM, Gonzalez FJ, Desvergne B, Wahli W: Peroxisome proliferator-activated receptor a mediates the adaptive response to fasting. J Clin Invest 1999, 103:1489-1498.

5. Mandard S, Müller M, Kersten S: Peroxisome proliferator receptor a target genes. Cell Mol Life Sci 2004, 61:393-416.

6. Ringseis $R$, Wen $G$, Eder $K$ : Regulation of genes involved in carnitine homeostasis by PPARa across different species (rat, mouse, pig, cattle, chicken, and human). PPAR Res 2012, 2012:868317.

7. Fischer M, Keller J, Hirche F, Kluge H, Ringseis R, Eder K: Activities of gammabutyrobetaine dioxygenase and concentrations of carnitine in tissues of pigs. Comp Biochem Physiol A Mol Integr Physiol 2009, 153:324-331.

8. Wen $G$, Ringseis $R$, Eder K: Mouse OCTN2 is directly regulated by peroxisome proliferator-activated receptor a (PPARa) via a PPRE located in the first intron. Biochem Pharmacol 2010, 79:768-776.

9. Wen G, Kühne $H$, Rauer $C$, Ringseis R, Eder K: Mouse $\gamma$-butyrobetaine dioxygenase is regulated by peroxisome proliferator-activated receptor a through a PPRE located in the proximal promoter. Biochem Pharmacol 2011, 82:175-183.

10. Wen G, Ringseis R, Rauer C, Eder K: The mouse gene encoding the carnitine biosynthetic enzyme 4-N-trimethylaminobutyraldehyde dehydrogenase is regulated by peroxisome proliferator-activated receptor a. Biochim Biophys Acta 1819, 2012:357-365.

11. Loor JJ, Dann HM, Everts RE, Oliveira R, Green CA, Janovick Guretzky NA, Rodriguez-Zas SL, Lewin HA, Drackley JK: Temporal gene expression profiling of liver from periparturient dairy cows reveals complex adaptive mechanisms in hepatic function. Physiol Genomics 2005, 23:217-226.

12. Loor JJ, Everts RE, Bionaz M, Dann HM, Morin DE, Oliveira R, Rodriguez-Zas SL, Drackley JK, Lewin HA: Nutrition-induced ketosis alters metabolic and signaling gene networks in liver of periparturient dairy cows. Physiol Genomics 2007, 32:105-116.

13. van Dorland HA, Richter S, Morel I, Doherr MG, Castro N, Bruckmaier RM: Variation in hepatic regulation of metabolism during the dry period and in early lactation in dairy cows. J Dairy Sci 2009, 92:1924-1940.

14. Schlegel G, Keller J, Hirche F, Geißler S, Schwarz FJ, Ringseis R, Stangl Gl, Eder K: Expression of genes involved in hepatic carnitine synthesis and uptake in dairy cows in the transition period and at different stages of lactation. BMC Vet Res 2012, 8:28.

15. Washburn KE, Powell JG, Maxwell CV, Kegley EB, Johnson Z, Fakler TM: A successful method of obtaining percutaneous liver biopsy samples of sufficient quantity for trace mineral analysis in adult swine without the aid of ultrasound. J Swine Health Prod 2005, 13:126-130.

16. Keller J, Ringseis R, Koc A, Lukas I, Kluge H, Eder K: Supplementation with $\mathrm{L}$-carnitine downregulates genes of the ubiquitin proteasome system in the skeletal muscle and liver of piglets. Animal 2012, 6:70-78.

17. Hirche F, Fischer M, Keller J, Eder K: Determination of carnitine, its short chain acyl esters and metabolic precursors trimethyllysine and $\gamma^{-}$ butyrobetaine by quasi-solid phase extraction and MS/MS detection. J Chromatogr B 2009, 877:2158-2162.

18. Kroetz DL, Yook P, Costet P, Bianchi P, Pineau T: Peroxisome proliferatoractivated receptor a controls the hepatic CYP4A induction adaptive response to starvation and diabetes. J Biol Chem 1998, 273:31581-31589.

19. Goto T, Takahashi N, Kato S, Egawa K, Ebisu S, Moriyama T, Fushiki T, Kawada T: Phytol directly activates peroxisome proliferator-activated receptor a (PPARa) and regulates gene expression involved in lipid metabolism in PPARa-expressing HepG2 hepatocytes. Biochem Biophys Res Commun 2005, 337:440-445.

20. Ringseis R, Luci S, Spielmann J, Kluge H, Fischer M, Geissler S, Wen G, Hirche $\mathrm{F}$, Eder $\mathrm{K}$ : Clofibrate treatment up-regulates novel organic cation transporter (OCTN)-2 in tissues of pigs as a model of non-proliferating species. Eur J Pharmacol 2008, 583:11-17.

21. Ringseis R, Wege N, Wen G, Rauer C, Hirche F, Kluge H, Eder K: Carnitine synthesis and uptake into cells are stimulated by fasting in pigs as a model of nonproliferating species. J Nutr Biochem 2009, 20:840-847. 
22. Musser RE, Goodband RD, Tokach MD, Owen KQ, Nelssen JL, Blum SA, Campbell RG, Smits R, Dritz SS, Civis CA: Effects of L-carnitine fed during lactation on sow and litter performance. J Anim Sci 1999, 77:3296-3303.

23. Birkenfeld C, Doberenz J, Kluge H, Eder K: Effect of L-carnitine supplementation of sows on L-carnitine status, body composition and concentrations of lipids in liver and plasma of their piglets at birth and during the suckling period. Anim Feed Sci Technol 2006, 129:23-28.

24. Musser RE, Goodband RD, Tokach MD, Owen KQ, Nelssen JL, Blum SA, Dritz SS, Civis CA: Effects of L-carnitine fed during gestation and lactation on sow and litter performance. J Anim Sci 1999, 77:3289-3295.

25. Musser RE, Dritz SS, Davis DL, Tokach MD, Nelssen JL, Goodband RD, Owen $\mathrm{KQ}$ : Effects of L-carnitine in the gestating sow diet on fetal muscle development and carcass characteristics of the offspring. J Appl Anim Res 2007, 31:105-111.

26. Brown KR, Goodband RD, Tokach MD, Dritz SS, Nelssen JL, Minton JE, Higgins JJ, Woodworth JC, Johnson BJ: Growth characteristics, blood metabolites, and insulin-like growth factor system components in maternal tissues of gilts fed L-carnitine through day seventy of gestation. J Anim Sci 2007, 85:1687-1694.

27. Ramanau A, Kluge H, Spilke J, Eder K: Effects of supplementation of $\mathrm{L}$-carnitine on the reproductive performance of sows in stock production. Livest Sci 2008, 113:34-42.

28. Eder K: Influence of L-carnitine on metabolism and performance of sows. Br J Nutr 2009, 102:645-654.

doi:10.1186/1751-0147-55-24

Cite this article as: Rosenbaum et al:: Genes involved in carnitine synthesis and carnitine uptake are up-regulated in the liver of sows during lactation. Acta Veterinaria Scandinavica 2013 55:24.

\section{Submit your next manuscript to BioMed Central and take full advantage of:}

- Convenient online submission

- Thorough peer review

- No space constraints or color figure charges

- Immediate publication on acceptance

- Inclusion in PubMed, CAS, Scopus and Google Scholar

- Research which is freely available for redistribution

Submit your manuscript at www.biomedcentral.com/submit 